\title{
Article \\ Premises for the Future Deployment of Automated and Connected Transport in Romania Considering Citizens' Perceptions and Attitudes towards Automated Vehicles
}

\author{
Liliana Andrei ${ }^{1}$ D, Mihaela Hermina Negulescu ${ }^{2}$ and Oana Luca ${ }^{1, * \mathbb{D}}$ \\ 1 Faculty of Civil, Industrial and Agricultural Engineering, Technical University of Civil Engineering, \\ 020396 Bucharest, Romania; liliana.capra@phd.utcb.ro \\ 2 Faculty of Urban Planning, Ion Mincu University of Architecture and Urbanism, 010014 Bucharest, Romania; \\ arh.mihaela.negulescu@gmail.com \\ * Correspondence: oana.luca@utcb.ro
}

Citation: Andrei, L.; Negulescu, M.H.; Luca, O. Premises for the Future Deployment of Automated and Connected Transport in Romania Considering Citizens' Perceptions and Attitudes towards Automated Vehicles. Energies 2022, 15, 1698. https://doi.org/10.3390/en15051698 Academic Editor: Omar Hegazy

Received: 28 January 2022

Accepted: 22 February 2022

Published: 24 February 2022

Publisher's Note: MDPI stays neutral with regard to jurisdictional claims in published maps and institutional affiliations.

Copyright: (C) 2022 by the authors. Licensee MDPI, Basel, Switzerland. This article is an open access article distributed under the terms and conditions of the Creative Commons Attribution (CC BY) license (https:// creativecommons.org/licenses/by/ $4.0 /)$.

\begin{abstract}
This paper is an initial exploratory study that provides recommendations for the sustainable development of future automated and connected transport (ACT) systems in Romania. To achieve this, our paper investigates the different factors that influence mobility behaviour related to ACT systems through two different themes. The first part analyses (i) the strategic framework that is relevant to future ACT deployment and (ii) the spatial development patterns of large cities in Romania that might influence future mobility behaviour based on ACT systems. We presumed, and the study confirmed, that there is currently a poor focus on ACT systems in strategic documents and that the current spatial patterns show some premises for unsustainable mobility behaviour based on ACT systems. The second part describes the results of our analysis on the WISE-ACT survey deployed in Romania. We explored how informed Romanian citizens are about AVs; whether they are ready to use them; and what perceptions, concerns, and attitudes might influence their mobility behaviour when using ACT systems. The present analysis mainly shows that the perceptions of Romanian citizens are widely similar to those of citizens from other countries and that, for Romania, the orientation towards unsustainable forms of individual travel is maintained in terms of the future use of AVs. The recommendations that are presented here primarily address the spatial and attitudinal factors that have been identified as prerequisites for unsustainable future mobility behaviour linked to ACT systems.
\end{abstract}

Keywords: automated and connected transport (ACT); sustainable mobility; statistical research; automated vehicles (AVs); citizens' perception and attitudes

\section{Introduction}

New Automated Vehicle technology (AV) has made Automated Connected Transportation (ACT) the heart of the emerging paradigm of smart and sustainable mobility. Although it is in a very early stage, ACT has the potential to cause disruptive changes in mobility habits and behaviour, both in a beneficial manner (transport optimisation and resilience, externality mitigation) and in a negative way (increasing the share and volumes of car-use and related unsuitable impacts) if not well managed. Future AV deployment has to be designed in line with the sustainable mobility paradigm, harnessing its beneficial potential and mitigating its eventual negative effects.

The smart mobility paradigm is the result of a continuous and ongoing process of reformulating principles, models, urban mobility planning methods, and transportation for social, economic, and environmental sustainability. These changes started in the 1970s as awareness of negative environmental trends caused by pollution and as urban living quality deteriorated, both of which were created by car-centric mobility [1-3]. David Banister theorized the change towards a sustainable mobility paradigm, referring to the 
(un)sustainability of transport, to travel time understood as demand, and to the social acceptance of change. Banister highlighted both the need to change transport organization [1] and also the need to change the characteristics of urban forms that influence travel demand and mobility behaviour. Banister, Andrés Duany, and Elizabeth Plater-Zyberk [1,4] highlighted the correlation between the high rate of car use and car-dependent, low-density, and sprawling urban developments [5]. This type of spatial development has become quite widespread in Romania in the last 30 years, supporting high car dependency and car-centric mobility behaviour. To achieve sustainable mobility, Banister identified relevant principles for urban development, such as functional mixity, higher density, and street redesign. The authors of [1,2,5-9] also criticised car-based modernist urban planning from the perspective of city quality while also emphasizing the need to develop spatial premises for walkability and for a larger share of non-motorized travel methods. In the last two decades, beyond the need for "cities for people" [8], the urgent need for climate-change mitigation has become a main and strong concern, accelerating actions related to changes in mobility patterns through the logic of sustainability. This urgency must also trigger more firm strategies to reshape cities in order to create spatial and functional premises for sustainable mobility by also taking the new challenges that could emerge from AV deployment into account. A significant change in mobility patterns, with unpopular demands related to reducing car ownership and car use, implies an increase in the awareness that citizens have as well as their acceptance, leading to changes in their attitudes and behaviour regarding mobility. This can be achieved inter alia (e.g., along with ecological education) through social-oriented measures that have been designed within mobility policies (communication campaigns, costs, tariffs, rules of access, incentives, etc.) [2,3]. To shape mobility habits related to AV use, a good understanding of our current perceptions and attitudes towards new forms of transportation is needed.

To synthesize, sustainable mobility responds holistically $[1,3]$ to accessibility requirements as well as to those of economic, social, and environmental sustainability. It is a mobility system that ensures good multimodal, (physically and economically) inclusive accessibility while also having a low ecological footprint and being harmoniously integrated into the urban living environment [3]. Since 2007, the European Commission (EC) has been constantly developing a programmatic European framework for sustainable urban mobility to support, the evolution of European cities towards being able to sustainably transport people and goods, in line with the principle of subsidiarity. The Sustainable Urban Mobility Plan (SUMP) was designed and promoted as a new integrated mobility planning tool. Currently, the EC is supporting the upgrade of the sustainable mobility paradigm by adding new concerns regarding evolution towards smart mobility and Intelligent Transport Systems (ITS) [10] in the sense of using the advantages of digitization to improve transport through optimization and resilience. These new concerns related to foreseeable disruptive changes to transportation are currently mostly focused on technical and technological aspects and on developing a legislative, strategic, and physical ecosystem for ACT development. This study plans to summarise and model our understanding of the relationship between AV users and the related ACT in terms of both the general accepted behavioural aspects as well as the peculiar ones resulting from each country's context.

To respond to these concerns, in recent years, there has been an increasing number of studies that have been conducted around the world that have used empirical research to investigate public perceptions regarding vehicle automation technologies. Our study undertakes a similar first step to understand the perceptions and attitudes of Romanian citizens toward AVs and makes relevant recommendations based on the conclusions of the survey developed during the COST WISE-ACT project deployed in Romania.

\section{Objectives of the Paper}

The aim of this paper is to provide a first interdisciplinary exploratory study on ACT in Romania by linking (i) an analysis of the spatial development characteristics influencing mobility patterns (ii) an analysis of a strategic framework that is relevant for future ACT 
deployment, and (iii) an analysis of citizen perceptions and attitudes towards automated vehicles (AVs), influencing future mobility behaviour related to ACT.

Five research objectives are proposed: (1) to provide the first review of ACT- and AV-related planning in strategic documents in Romania; (2) to perform a general exploration of the urban context in Romania, which influences current mobility behaviour and, presumably, also influences future mobility behaviour when ACT is implanted; (3) to perform a literature review in order to compare the perceptions of Romanian citizens on $\mathrm{AVs}$ with those of citizens from other countries, with a specific focus on the south-east European region; (4) to explore the citizens' perceptions and factors that influence attitudes related to automated vehicles in Romania for the first time based on the findings of the COST WISE ACT survey; and (5) to discuss the results of the four previous analyses to formulate recommendations for future ACT development in Romania. Our research is expected to contribute to the broad knowledge base surrounding AVs, particularly in the Romanian contexts.

The paper is organized as follows: Section 2 details the materials and methods utilized in this work. In Section 3, the results are presented. Finally, Section 4 presents the discussion, conclusion, and recommendations.

\section{Materials and Methods}

\subsection{Conceptual Assumptions}

Based on the objectives of the paper and our academic and professional knowledge, we propose the following assumptions:

Assumption 1: There is a poor ACT planning focus in strategic documents in Romania (research objective 1).

Assumption 2: The current spatial patterns of large cities and the Functional Urban Areas (FUAs) of those cities in Romania are the premises for unsustainable mobility patterns that are based on ACT (research objective 2).

Assumption 3: Romanian citizens have limited knowledge regarding AVs (research objective 4 ).

Assumption 4: The perceptions of Romanian citizens are similar to those of citizens from other countries (research objectives 3 and 4).

Assumption 5: An orientation towards unsustainable forms of AV travels (individual $\mathrm{AV}$ use) is maintained and accentuated, and there is poor willingness to use Avs as a collective (research objectives 1, 3 and 4).

Corresponding to research objective 1 , to identify the current state of planning for ACT future deployment (related infrastructure, vehicles, and services), a study on the national and local planning framework for transport and mobility in Romania (strategies for transport, SUMPs) was carried out.

Corresponding to the research objective 2 , to understand spatial influences on future ACT-related mobility behaviour, we characterised the urban development patterns for large cities and their functional urban areas (FUAs) in Romania, focusing on the main functional and spatial aspects with high relevance for the current mobility patterns [1-3,5]: (i) type of growth (extensive/intensive, compact/urban sprawl); (ii) functional aspects (mono-functionality/functional mix, public facilities, level of functional dependence of peri-urban areas on main cities); and (iii) density. Furthermore, to highlight the travel habits influencing the future ACT-related mobility behaviour, we performed a general characterisation of the mobility patterns in large cities in Romania and in the Functional Urban Areas (FUAs) of those cities in terms of (i) current transport supply patterns and (ii) mobility behaviour. Both general characterisations of spatial patterns and mobility patterns in the large Romanian cities and in their FUAs are synthesized based on numerous research studies [11-13] and urban planning studies (general master plans, strategies of urban development, e.g., for Bucharest, Sibiu, Braila) on these topics and SUMPs (e.g., for Bucharest-Ilfov, Sibiu, Ploiesti, Craiova, Bacau), each of which had the participations of at least one of the present authors. 
Corresponding to research objective 3, a relevant literature review covering studies related to citizen perceptions of AVs was performed while focussing on SEE countries.

Corresponding to research objective 4, the WISE-ACT survey was conducted in different European countries, including Romania, to determine citizen perceptions and attitudes towards automated vehicles (AVs) during the deployment of the WISE-ACT COST action.

Discussions on the five assumptions and policy recommendations are provided, corresponding to research objective 5 .

\subsection{Description of the Survey, Variables, Measurement Scale, and Data Processing Tool}

To explore citizen perceptions and attitudes towards automated vehicles (AVs), we used the large-scale web-based survey designed by the WISE-ACT COST action. The survey investigated daily transport habits specific to our most important journeys and the modes of transport used as well as awareness, perception, and attitudes towards autonomous vehicles. It has previously been deployed in most European countries, and for this study, we used the responses provided by Romanian participants.

Socio-economic characteristics such as age, gender, disability, education, and income, were collected. In Romania, we contacted a wide range of people to cover the following sampling criteria: gender, age, most used mode of transport, education level, household size, and whether the participants had any known disabilities, reaching a total number of 309 people. The sample was distributed to various stakeholders at both the national and local levels, such as interest groups, public transport operators, national road agencies, universities, cycling groups, car clubs, and citizens. The survey was designed in English for all of the countries participating in the WISE ACT action, and it was then translated into Romanian.

A definition of $\mathrm{AVs}$ has been included to avoid any misunderstanding: "An autonomous vehicle (AV) is a vehicle that takes full and permanent control of speed and direction, on all roads and in all situations." Respondents were asked to consider a fully automated vehicle, i.e., an autonomous vehicle according to the SAE (Society of Automotive Engineers) level 5. The survey received ethical approval, and the data were collected anonymously between January-March 2021. The survey was performed in the second wave of the COST Action.

A six-point Likert scale was used to evaluate the attitudinal variables and of those measuring user perceptions and preferences, in line with contemporary research [14]. Table 1 presents the selected variables and provides a description of them as well the scale of measurement.

Table 1. The framework of the variables and scales of measurement used for analysis.

\begin{tabular}{|c|c|c|}
\hline Variable & Description & Scale of Measurement \\
\hline \multirow{3}{*}{$\begin{array}{l}\text { Current travel } \\
\text { behaviour and } \\
\text { motivations }\end{array}$} & $\begin{array}{l}\text { What is the purpose of the most important journey of yours? (Going to } \\
\text { work or other professional reasons, go to school, college, or university, } \\
\text { or to attend another educational activity; to complete groceries, } \\
\text { errands, administrative tasks, medical appointments, etc., to pick-up or } \\
\text { drop someone off, visiting someone, leisure, or I do not have any } \\
\text { important journeys) }\end{array}$ & Categorical scale (ordinal) \\
\hline & $\begin{array}{l}\text { What is the main mode of transportation that you use for this } \\
\text { important journey? (private car, shared car, public transport, shuttle } \\
\text { service to work, private bicycle, motorbike, walking) }\end{array}$ & Categorical scale (ordinal) \\
\hline & $\begin{array}{l}\text { I choose .... } \text { the choice of the above question\} as my main transport } \\
\text { mode because of the... (travel cost, reliability, environmental impacts of } \\
\text { my travel, safety, time needed to reach my destination, service } \\
\text { frequency, available facilities, available connections with other modes } \\
\text { of transportation, travel information availability, personal security, lack } \\
\text { of alternatives, privacy) }\end{array}$ & $\begin{array}{l}\text { Continuous scale (Likert } \\
\text { scale: 1-total disagreement } \\
\text { to 6-total agreement) }\end{array}$ \\
\hline
\end{tabular}


Table 1. Cont.

\begin{tabular}{llc}
\hline \multicolumn{1}{c}{ Variable } & \multicolumn{1}{c}{ Description } & Scale of Measurement \\
\hline $\begin{array}{l}\text { Safety-related } \\
\text { experience }\end{array}$ & $\begin{array}{l}\text { How many accidents have you been involved in while driving a car in } \\
\text { the last 3 years? }\end{array}$ & Categorical scale (ordinal) \\
\hline
\end{tabular}

How often have you used Adaptive Cruise Control when driving a car

Knowledge and use of in the last 12 months? (every day; 4 to 6 days a week; 1 to 3 days a week; about once a fortnight; about once a month; less than once a month; never; I do not have ACC; I do not know what ACC is; I do not drive a car; I prefer not to respond)

I would travel in an Autonomous Vehicle (e.g., car, taxi, bus) with (without) the supervision of a human operator in the vehicle (remote)

Perception and preferences for

I would allow my children (under 16) to travel in an AV (e.g., car, taxi, bus) with (without) the supervision of a human operator in the vehicle (remote) using (shared) AVs

It is acceptable to travel with other unknown people in an Autonomous Vehicle for: ... (myself; my children under 16)

I would consider purchasing an Autonomous Vehicle ... (as soon as they become available; as soon as they become affordable; as soon as I am convinced about their usefulness; as soon as I am convinced about their safety; as soon as I am convinced about their reliability; only after I see them being used by others first)

Autonomous vehicles will ... (Benefits: reduce accidents, reduce traffic congestion, allow the use of travel time for non-driving activities, reduce travel stress, improve mobility options, decrease travel time,

Perception of benefits/treats related to $\mathrm{AVs}$ reduce greenhouse gas emissions, make travelling more comfortable)

Autonomous vehicles will ... (Threats: increase traffic congestion, increase the risk of personal assault or terrorist attacks, increase privacy risks, be a new target for cyber-attacks, reduce the pleasure of driving, reduce our freedom of travel, reduce the need for professional drivers)
Categorical scale (ordinal)

Continuous scale (Likert scale: 1 -total disagreement to 6-total agreement)

Continuous scale (Likert scale: 1 -total disagreement to 6 -total agreement)

Continuous scale (Likert scale: 1 -total disagreement to 6-total agreement)

Continuous scale (Likert scale: 1 -total disagreement to 6-total agreement)

Continuous scale (Likert scale: 1 -total disagreement to 6 -total agreement)

Continuous scale (Likert scale: 1 -total disagreement to 6-total agreement)

To analyse the survey results and to perform the correlations, we used the IBM SPSS Statistics Grand Pack 28.0 PREMIUM. IBM SPSS is designed to perform various statistical calculations, from descriptive statistics to inferential statistics, data management, and graphs, and it is a widely used research tool in engineering, marketing and education, the social sciences, healthcare, and data mining.

\section{Results}

\subsection{Results from Analysis of the Strategic Framework for Transport and Mobility Planning in Romania}

From 1990 to 2015, similar to in other SEE countries, strategic mobility planning was largely geared towards meeting the growing demand for motorised traffic and on-street parking, with little attention being paid to the externalities [3,15]. Since 2010, in the context of the European Urban Mobility Policy and within the adoption of the first phase of the Sustainable Urban Mobility Plans (SUMP) planning model [16], national and local strategic frameworks for transportation and mobility in Romania has been more firmly oriented towards satisfying sustainability demands. New mobility policies are currently being designed for the development of a more balanced and multimodal transport supply and to discourage and mitigate individual motorised travel and to achieve more sustainable mobility behaviour.

ACT is not yet a focal point during the strategic planning of transport and mobility in Romania [17-20]. However, a first pilot project (open interfaces for connected and automated vehicles on the Nadlac-Constanta motorway) is outlined in the Intelligent Transport 
Systems (ITS) Strategy Implementation Plan for Programme 5 (Cooperative ITS) to encourage the further development of intelligent infrastructure to support automated vehicles.

At the local level, SUMPs and other strategies with a mobility planning component do not yet explicitly contain ACT-related actions. Nevertheless, smart mobility-related projects that are aimed at the digitization of transport (ITS) are present in recently elaborated upon "smart city" strategies for some Romanian cities [21-23]. These smart mobility-oriented projects could be considered to be preliminary steps towards the future development of ACT ecosystems: charging infrastructures to accommodate electric vehicles, smart traffic management, smart platforms for public transport, smart stations, smart parking, and smart streets. Other large-scale projects, such as the deployment of $5 \mathrm{G}$ network infrastructure for communication purposes, have been implemented in the large Romanian cities, supporting the transition towards the smart city model.

Even though the few ACT-related projects that are planned in Romania at the national level have yet to be implemented, pilot projects are being designed locally in some large cities. For instance, Cluj has planned a pilot phase for AV implementation through 14 autonomous minibuses (with 10-12 seats) that will soon be purchased for public passenger transport. The city also plans to develop routes to test automated vehicles through the "Innovation, Testing and Promotion Centre Cluj" project. The first "smart street" has been also (re)arranged in Cluj.

\subsection{Results from Analysis of Spatial Development and Urban Mobility Patterns of the Large Cities in Romania}

Romania, alongside other post-communist countries in South-Eastern Europe, has undergone a series of complex societal transformations since 1990, the year the political regime changed. The transition towards a fully functional market economy has been long, and though these countries are developing quickly, they still have Gross Domestic Product (GDP) per inhabitant and the national average income levels that are considerably lower than those found in the rest of Europe.

After the release of the restrictions imposed before 1990, the majority of the large cities experienced two types of rapid but uncontrolled spatial development: (i) intensive spatial development through densification within cities and (ii) extensive spatial development in suburban areas (periphery) and peri-urban settlements (cities or small towns), with core cities being spatially and functionally stronger and connected into larger territories and accessed via daily commuting - Functional Urban Areas (FUAs) [3]. The extensive spatial growth has been triggered by new urban-rural social migration, and, in most cases, has partially followed the dysfunctional patterns of car-dependent urban sprawl (low density, low functional mix, underdeveloped public facilities, undersized road infrastructure) [3,24-27] because (i) the lengthy process of replacing the post-socialist institutional and urban planning frameworks (previously designed for centralised planning) with a new one that is more appropriate for managing new types of urban development and that is mainly based on medium- and small-scale private initiatives within a market economy and (ii) institutional and administrative weakness $[15,26,28]$. New built-up areas have been developed as a result of land opportunities and road accessibility, many of which lack or have poor accessibility to public transport [3,29]. In most cases, these areas have poor job opportunities and undiversified public facilities of daily interest (educational, healthcare, cultural facilities, etc.) nearby. Consequently, they often have a high level of functional dependence on the main ("magnet") cities and generate high amounts of commuter traffic, most of which is car-based.

In terms of mobility patterns, after the fall of the communist regime, private car use has been the strongest driving force supporting developments with extensive urban sprawl in Romania. The rate of car ownership has rapidly increased, reaching high levels in large cities, especially in the capital city, though the national average rates of motorizations are considerably lower than the local ones. Romania's capital, Bucharest, for instance, has a 
very high car ownership rate: 662.3 vehicles/1000 inhabitants (2017), while the national average is 357 vehicles/1000 inhabitants (2019) [30,31].

The dispersed spatial growth of large cities has largely been car-oriented and has generated high levels of motorised commuting. New and strongly car-centric travel behaviour has become dominant not only at the FUA level but also within large major cities [15,26,32], despite the fact that the latter usually have satisfactory public transport systems.

A significant proportion of people have become reluctant to use public transportation because of (i) two decades of mobility policy geared towards unconditionally satisfying the constantly growing demands of individual motorized traffic, (ii) the several unsatisfactory features of public transport, and (iii) the social perception of cars as a status symbol $[3,33]$.

A significant example of the mobility behaviour in large Romanian cities is in Bucharest, the capital city, which benefits from a good public transportation system. The modal share was estimated in the SUMP for Bucharest-Ilfov (2016) as being: use of private car: 36\%, use of public transport: $27 \%$, walking: $31 \%$, cycling: $2 \%$, and other: $4 \%$.

At the same time, people living in peri-urban areas who do not have a driver's licence (children, elderly, or disabled people) are often dependent on drivers (e.g., "taxi-parents") to access different activities and locations or face situations of captivity due to low accessibility to public transport.

The metropolisation patterns of most cities and the related unsustainable car-oriented travel behaviour has led to a wide range of social, spatial, economic, and environmental externalities: high levels of traffic, congestion, time loss, economic loss, high rates of injuries or road fatalities, the degradation of public spaces, pollution, and greenhouse gas emissions, which have affected both the accessibility and the liveability of large cities while also contributing to global warming and climate change $[3,26,28]$.

\subsection{Understanding Perceptions and Attitudes on AVs at South-Eastern European Level}

In this section, we reviewed several studies focusing on the possible impacts of AVs and user acceptance. However, we are not providing a detailed background on Avs, as their ecosystem and development have been covered in several other papers, such as [34-36].

In recent years, the international literature exploring the perceptions and attitudes of AVs using SP surveys has been extensive [37,38], and other studies [39-43] have shown different degrees of acceptability.

However, it was discovered that limited literature has been published on AV acceptance in SEE countries (Table 2). It is our belief that such a review is necessary to compare the perceptions of Romanian citizens on AVs with those of citizens from other SEE countries.

Table 2. Overview of the recent literature discussing SP surveys evaluating AVs acceptance in SEE countries.

\begin{tabular}{|c|c|c|c|c|c|}
\hline Source & Objective & $\begin{array}{c}\text { Countries/Responses } \\
\text { Analysed }\end{array}$ & Relevant Findings & Strengths & Limitations \\
\hline [14] & $\begin{array}{l}\text { Users' stated choices and } \\
\text { preferences regarding the } \\
\text { use and the } \\
\text { willingness-to-pay for } \\
\text { private (PAV) and shared } \\
\text { autonomous vehicles } \\
\text { (SAV) using a stated } \\
\text { preference } \\
\text { experiment survey. }\end{array}$ & $\begin{array}{l}\text { Total: } 1962 \\
\text { Cyprus-171 } \\
\text { Greece-130 } \\
\text { Hungary-321 } \\
\text { Israel-611 } \\
\text { Iceland-535 } \\
\text { Finland-100 } \\
\text { UK-94 }\end{array}$ & $\begin{array}{l}\text { Differences in behaviour between } \\
\text { the southern and northern } \\
\text { countries: travelling with women } \\
\text { has a positive effect on male } \\
\text { respondents in the southern cluster, } \\
\text { while both women and men would } \\
\text { prefer to avoid riding with one or } \\
\text { two men in at least in some } \\
\text { countries in the southern cluster. In } \\
\text { the northern cluster, women would } \\
\text { prefer to avoid riding with one man } \\
\text { in an SAV, while men prefer to } \\
\text { avoid riding with women or } \\
\text { mixed-gendered passengers. } \\
\text { Value of Time (VoT) for Shared } \\
\text { Automated Vehicle (SAV) is higher } \\
\text { than that of Private Automated } \\
\text { Vehicles (PAV) for all countries. }\end{array}$ & $\begin{array}{l}\text { Comparing } \\
\text { responses in the } \\
\text { Northern and } \\
\text { Southern cluster } \\
\text { (seven countries } \\
\text { in Europe) }\end{array}$ & $\begin{array}{l}\text { Heterogeneous } \\
\text { samples, mostly } \\
\text { attributed to different } \\
\text { sampling strategies in } \\
\text { the countries in } \\
\text { the research }\end{array}$ \\
\hline
\end{tabular}


Table 2. Cont.

\begin{tabular}{|c|c|c|c|c|c|}
\hline Source & Objective & $\begin{array}{c}\text { Countries/Responses } \\
\text { Analysed }\end{array}$ & Relevant Findings & Strengths & Limitations \\
\hline [44] & $\begin{array}{l}\text { Modelled user acceptance } \\
\text { in six } \\
\text { different countries and } \\
\text { discussing possible } \\
\text { implications of AV } \\
\text { acceptance as well as the } \\
\text { possibility of technology } \\
\text { assimilation versus } \\
\text { technology rejection in } \\
\text { different countries }\end{array}$ & $\begin{array}{l}\text { Total: } 1669 \\
\text { Cyprus-158 } \\
\text { UK-79, } \\
\text { Slovenia-274, } \\
\text { Montenegro-321 } \\
\text { Hungary-285, and } \\
\text { Iceland-552. }\end{array}$ & $\begin{array}{l}\text { Men favour AVs more than women } \\
\text { do; men were more willing to } \\
\text { purchase AVs and would pay more } \\
\text { for them; } \\
\text { older individuals may be more } \\
\text { hesitant towards AVs and prefer } \\
\text { private conventional cars. }\end{array}$ & $\begin{array}{l}\text { Survey in six } \\
\text { countries, } \\
\text { allowing common } \\
\text { conclusions }\end{array}$ & $\begin{array}{l}\text { unavoidable } \\
\text { inconsistencies in data } \\
\text { collection in } \\
\text { different countries. } \\
\text { lack of standardization } \\
\text { between countries in } \\
\text { the collected data, with } \\
\text { regard to the } \\
\text { socio-demographics of } \\
\text { the samples and } \\
\text { the sample } \\
\text { sizes, likely influencing } \\
\text { the comparability of } \\
\text { the samples }\end{array}$ \\
\hline [45] & $\begin{array}{l}\text { Users' anticipation of AV } \\
\text { safety and their overall } \\
\text { perspective on AVs. }\end{array}$ & $\begin{array}{l}\text { Total 1639: } \\
\text { Cyprus-158 } \\
\text { Greece-128 } \\
\text { Finland-101 } \\
\text { Iceland-561 } \\
\text { Italy-78 } \\
\text { Montenegro-309 } \\
\text { Malta-26 } \\
\text { Slovenia-278 }\end{array}$ & $\begin{array}{l}\text { Importance of factors other than } \\
\text { safety on public acceptance of AVs } \\
\text { and potential uptake of the } \\
\text { automated technology; factors such } \\
\text { as reliability, affordability, cost, } \\
\text { driving pleasure, } \\
\text { and household size may affect AV } \\
\text { uptake; thus, they should not be } \\
\text { neglected when designing AV } \\
\text { introduction and } \\
\text { deployment policies. }\end{array}$ & $\begin{array}{l}\text { Survey applied in } \\
\text { eight countries }\end{array}$ & $\begin{array}{l}\text { Most of the survey } \\
\text { participants were } \\
\text { male, which does not } \\
\text { necessarily represent } \\
\text { the national gender } \\
\text { quota; no children } \\
\text { participated in the } \\
\text { survey due to the } \\
\text { applicable research } \\
\text { ethics framework }\end{array}$ \\
\hline
\end{tabular}

The concept of

autonomous vehicles was presented, and the way it was perceived by users of traditional cars was reported.

Surveys were carried out on the possibilities of

$[36,46] \quad$ developing AVs in Poland. 579 people in Poland

AVs will improve road safety and create energy consumption savings. Obstacles to AV deployment include legal liability, ethical issues, privacy concerns, cybersecurity, high costs.

Due to many different factors, including costs, legal regulations, and conviction, among others, $\mathrm{AVs}$ will not be a common fixture on Polish roads and will likely require a 20-year adaptation period.
Detailed description of automation level; evaluation of barriers to $\mathrm{AV}$ deployment
Most of the respondents were men, young people 18-25 years old, with secondary or higher education their particularly in terms of the advantages and disadvantages of this solution, we identified.
Presents the results of queries in Serbia among a wide portion of the population
Interview with 150 people in Serbia
Acceptance of self-driving vehicles will decrease pollution, reduce, or eliminate parking spaces, will create cybersecurity and privacy issues; and is good for disabled. Most people in Serbia were sceptical of self-driving cars; education and dissemination of knowledge on the topic is necessary.

Travellers will reduction in travel time once conventional transport modes are replaced by AVs; a decrease in the value of time (VOT) of AVs increases the usage of AVs, and it particularly decreases the usage of cars even more than other transport modes. AVs strongly affect public transport when the VOT of AVs becomes close to the VOT of public transport.

One AV can replace 7.85 conventional vehicles with an acceptable waiting time.
Use of interviews to allow participants receiving more explanations and ensuring enriched discussions
Small number of people involved; not clear if they are representative for Serbia
Developed a base model to determine the required AV deet size to fulfil the

[48] groups of travellers and predicted the new modal shares of the transport modes when AVs appear on the market
8500 travellers who recorded their daily activity plans in
Use of three scenarios to
determine the impact of AVs on conventional modes of transportation; large group of respondents
Study does not focus on the impact of the AVs on traffic conditions, and it only concerned travel time. The increase in the demand for AVs from specific user groups was not considered, such as individuals with disabilities

As seen from the above table, how citizens perceive $A V s$ has not been tested in Romania before this study. Table 2 shows that there is ongoing research in SEE countries, with some countries (Cyprus, Greece, Montenegro, Hungary) already leading the way in studying the perceptions and attitudes of their citizens. Most of the findings are in 
accordance with the general findings determined in the review of the international literature, revealing the strong points of AVs, such as improving road safety [49] and reducing environmental pollution [50] but also demonstrating the main concerns related to security and privacy $[38,51]$. Including the interviews would allow a better understanding of the $\mathrm{AVs}$, and enriched discussions. However, the main limitation is related to the small number of people involved in the survey.

\subsection{Results from Analysis of the Survey Results}

The analysis considers socio-demographic characteristics, travel behaviour, knowledge about AVs, and the influence of socio-demographic characteristics on attitudes towards AVs (acceptance, sharing, purchasing).

It focuses on perceptions related to the benefits and threats of using AVs and attitudes towards using them individually or collectively.

A total of 309 responses were recorded and validated. Most of the people who responded to the survey were between 20 and 49 years old and comprised the portion of the population with access to the internet. The sample was balanced in terms of gender representation. Most of the respondents had received college or university education $(44,7 \%)$, and a high percentage of the respondents received postgraduate education $(40.8 \%)$. In terms of income, there was a uniform distribution among the respondents, with 11\% in the middle-income range. A relatively high percentage of the respondents $(18.4 \%)$ did not want to disclose their income. The socio-demographic characteristics of the sample are presented in Table 3.

In terms of transport habits, the majority of the respondents declared that the purpose of their most important trip is to go to work (67.31\%), followed by other professional reasons $(7.77 \%)$ (Figure 1$)$. The main most of transportation used to achieve his purpose were as follows: private car (56.67\%) followed by public transport (25\%) (Figure 2).

Table 3. Socio-demographic characteristics of the Romanian sample (Source: Authors' survey data).

\begin{tabular}{|c|c|c|c|}
\hline \multicolumn{2}{|c|}{ Socio-Demographic Variables } & Frequency & Percent \\
\hline \multirow{8}{*}{ Age } & Under 19 & 1 & 0.3 \\
\hline & $20-29$ & 60 & 19.4 \\
\hline & $30-39$ & 100 & 32.4 \\
\hline & $40-49$ & 70 & 22.7 \\
\hline & $50-59$ & 58 & 18.8 \\
\hline & $60-69$ & 16 & 5.2 \\
\hline & $70-79$ & 3 & 1.0 \\
\hline & Over 80 & 1 & 0.3 \\
\hline \multirow{2}{*}{ Gender } & Women & 155 & 50.2 \\
\hline & Men & 154 & 49.8 \\
\hline \multirow{5}{*}{ Highest educational degree } & Primary school or equivalent & 1 & 0.3 \\
\hline & High school & 30 & 9.7 \\
\hline & College / University & 138 & 44.7 \\
\hline & Postgraduate & 126 & 40.8 \\
\hline & Other & 14 & 4.5 \\
\hline
\end{tabular}


Table 3. Cont.

\begin{tabular}{|c|c|c|c|}
\hline \multicolumn{2}{|c|}{ Socio-Demographic Variables } & \multirow{2}{*}{$\begin{array}{c}\text { Frequency } \\
209\end{array}$} & \multirow{2}{*}{$\begin{array}{c}\text { Percent } \\
67.6\end{array}$} \\
\hline \multirow{7}{*}{ Current employment status } & Employee & & \\
\hline & Self-employed & 26 & 8.4 \\
\hline & Company owner & 36 & 11.7 \\
\hline & Unemployed & 1 & 0.3 \\
\hline & Retired & 8 & 2.6 \\
\hline & Full-time education & 23 & 7.4 \\
\hline & Other & 6 & 1.9 \\
\hline \multirow{5}{*}{ Mobility-reducing disabilities } & No known disability & 289 & 93.5 \\
\hline & Mobility issues & 3 & 1.0 \\
\hline & Visual impairment & 3 & 1.0 \\
\hline & I prefer not to respond & 13 & 4.2 \\
\hline & Other & 1 & 0.3 \\
\hline \multirow{2}{*}{ Driving license } & No & 53 & 17.2 \\
\hline & Yes & 256 & 82.8 \\
\hline \multirow{6}{*}{ No. of cars in the household } & 0 & 46 & 14.9 \\
\hline & 1 & 141 & 45.6 \\
\hline & 2 & 99 & 32.0 \\
\hline & 3 & 18 & 5.8 \\
\hline & 4 & 4 & 1.3 \\
\hline & 5 & 1 & 0.3 \\
\hline
\end{tabular}

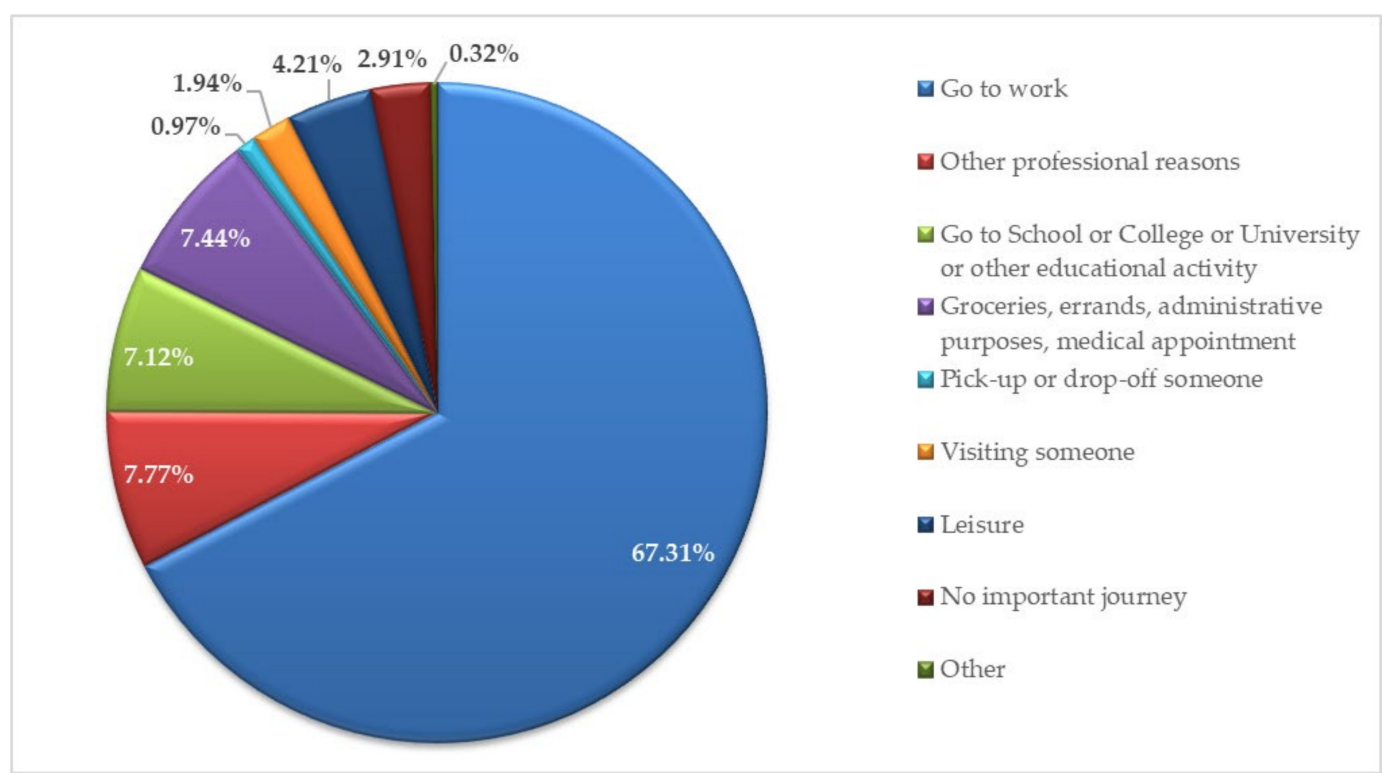

Figure 1. Purpose of main trip (Source: Authors' survey data processing). 


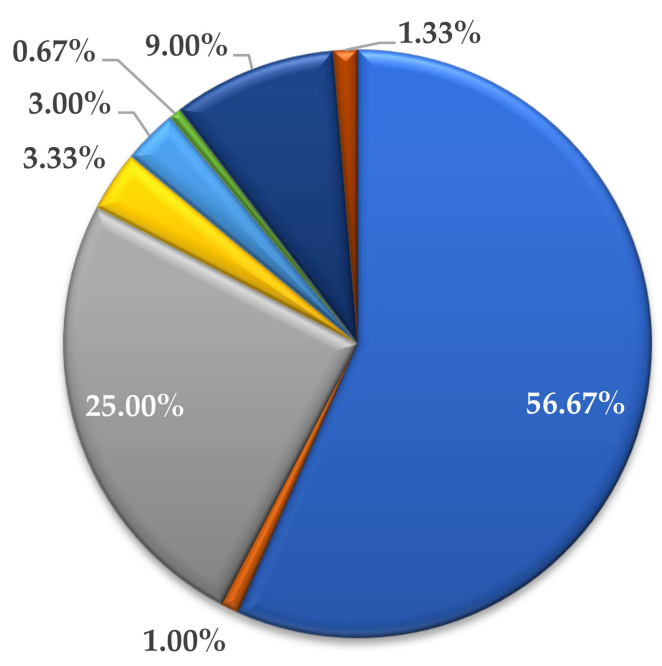

- Private car

$\square$ Shared car

Public transport

$\square$ Shuttle service to work

๑ Private bicycle

Motorbike

Walking

Other

Figure 2. Modal share for the most important trip. (Source: Authors' survey data).

Table 4 presents the determinants for choosing the mode of transportation used for each participant's most important trip, which was based on the statistical mean (M) calculated by considering a Likert scale that ranged from $1=$ strongly disagree to $6=$ strongly agree. A total of 296 responses were considered because 309 declared that they do not take any important journeys.

Table 4. Factors that determine the mode of transportation for the respondents' most important trips.

\begin{tabular}{|c|c|c|c|c|c|c|c|}
\hline & \multicolumn{7}{|c|}{ What Is the Main Mode of Transport You Use for This Important Journey? } \\
\hline & $\begin{array}{l}\text { Private } \\
\text { Car }\end{array}$ & $\begin{array}{l}\text { Shared } \\
\text { Car }\end{array}$ & $\begin{array}{c}\text { Public } \\
\text { Transport }\end{array}$ & $\begin{array}{c}\text { Shuttle Service } \\
\text { to Work }\end{array}$ & $\begin{array}{l}\text { Private } \\
\text { Bicycle }\end{array}$ & Motorbike & Walking \\
\hline No. of responses & 170 & 3 & 75 & 10 & 9 & 2 & 27 \\
\hline $\begin{array}{l}\text { I choose... as my main transport } \\
\text { mode because of... }\end{array}$ & & & & Mean (M) & & & \\
\hline Travel cost & 2.86 & 5.33 & 4.76 & 5.20 & 4.78 & 3.50 & 4.15 \\
\hline $\begin{array}{l}\text { Reliability (e.g., arriving at the } \\
\text { expected time) }\end{array}$ & 5.02 & 4.67 & 3.75 & 4.20 & 5.44 & 6.00 & 5.22 \\
\hline $\begin{array}{l}\text { Environmental impacts of my } \\
\text { travel (e.g., air pollution) }\end{array}$ & 2.21 & 2.33 & 4.24 & 4.10 & 5.22 & 5.50 & 5.11 \\
\hline Safety (e.g., travel accidents) & 4.68 & 3.33 & 4.15 & 3.70 & 3.11 & 2.00 & 4.33 \\
\hline $\begin{array}{l}\text { Time needed to reach } \\
\text { my destination }\end{array}$ & 5.19 & 4.00 & 4.29 & 4.30 & 5.33 & 6.00 & 4.93 \\
\hline Service frequency & 5.06 & 4.67 & 4.19 & 4.80 & 5.00 & 6.00 & 4.70 \\
\hline $\begin{array}{l}\text { Available facilities (e.g., parking } \\
\text { slots, seat, Wi-Fi) }\end{array}$ & 4.31 & 2.67 & 3.03 & 4.20 & 2.89 & 4.50 & 2.67 \\
\hline $\begin{array}{l}\text { Available connections with other } \\
\text { transport modes }\end{array}$ & 2.88 & 1.33 & 4.32 & 4.30 & 1.89 & 2.00 & 3.52 \\
\hline Travel information availability & 3.81 & 1.33 & 3.80 & 4.80 & 2.33 & 1.00 & 3.56 \\
\hline $\begin{array}{l}\text { My personal security (e.g., risk of } \\
\text { assault, aggressive behaviour) }\end{array}$ & 4.81 & 3.33 & 3.52 & 4.50 & 3.00 & 3.50 & 3.33 \\
\hline Lack of alternatives & 3.99 & 5.33 & 4.27 & 3.60 & 3.00 & 4.50 & 3.19 \\
\hline Privacy options & 4.09 & 2.00 & 3.04 & 3.60 & 2.56 & 6.00 & 3.11 \\
\hline
\end{tabular}


The survey participants were questioned about their level of knowledge and experience regarding autonomous vehicles through two questions: whether they had heard about autonomous vehicles before and whether they had ridden in an autonomous vehicle before. A total of 224 of them said that they had heard about Avs, and only 34 said that they had ridden in one. Figure 3 depicts how in general, younger people have much more knowledge about AVs, with $33.5 \%$ of those who answered yes to this question being included in the 30-39 age group. Among those who declared that they had travelled in an AV (Figure 4), the preponderance of young people aged 30-39 can be observed once again, i.e., $41.2 \%$. This leads to the conclusion that young people are much more informed about technological developments and that they are probably more willing to test them.

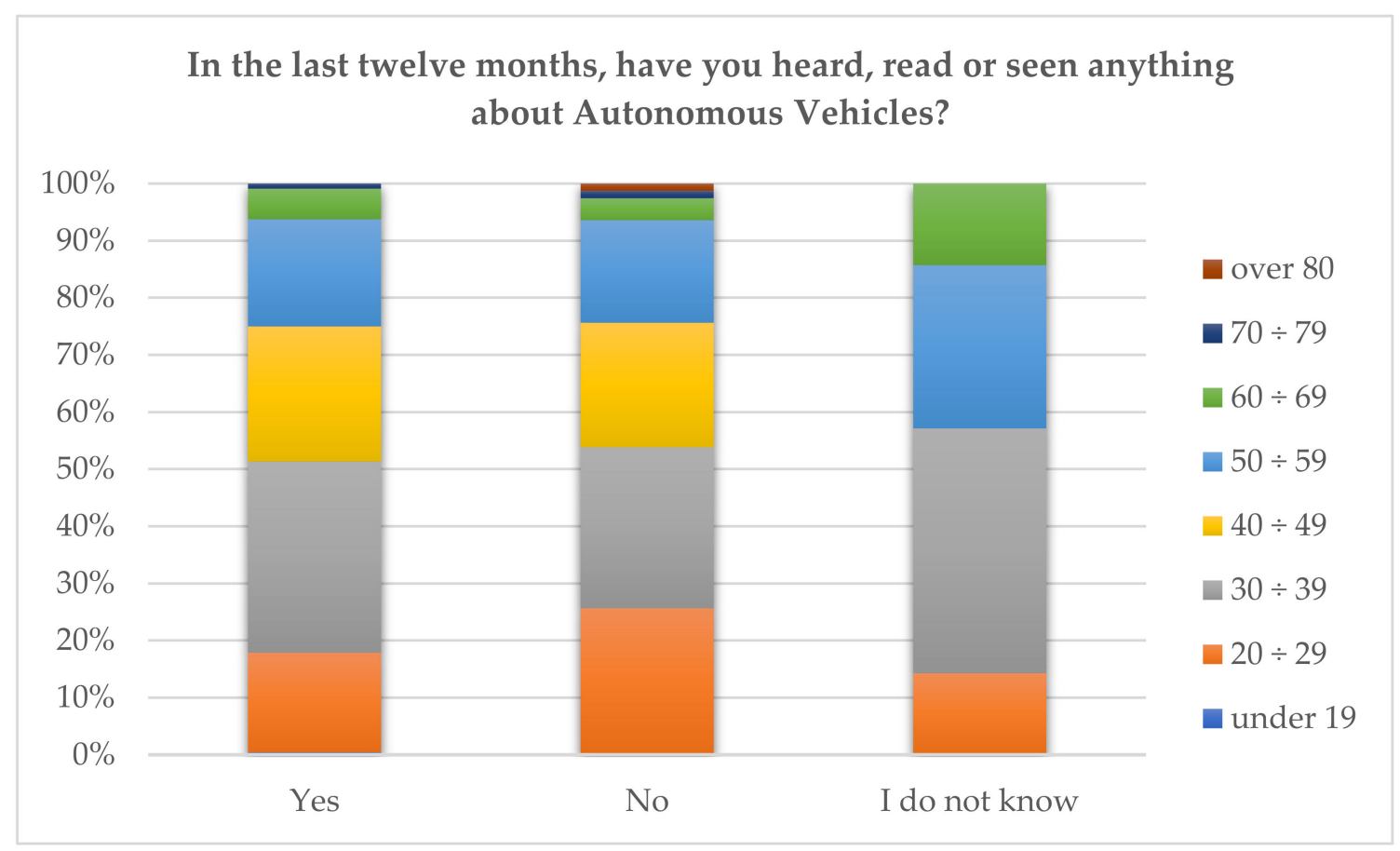

Figure 3. Knowledge about AVs.

Have you ever travelled in an Autonomous Vehicle?

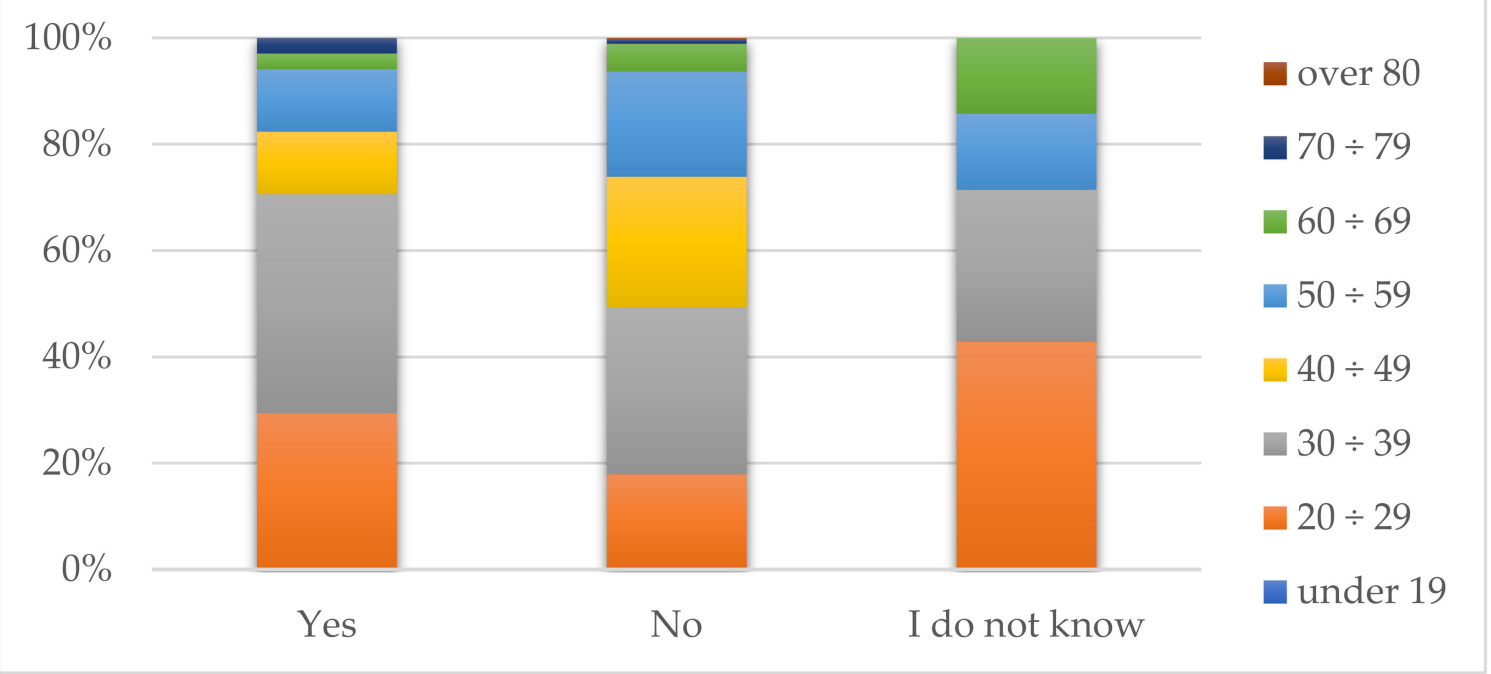

Figure 4. Experience with AVs. 
The following section presents the correlation between the socio-demographic variables (gender, age, education, employment status, members in the household, members in the household who need care, disability, gross annual household income, driver's licence, number of the operational cars in the household), other survey variables (transport mode used for the main travel purpose, car accidents in the last 3 years, use of Adaptive Cruise Control), and variables related to AV acceptance. For this purpose, because the nature of the distribution of the parameters is not known or differs from the normal distribution, the data are ranked according to an ordered Likert scale for some variables, and for others, such as main mode of transportation used, where a private car is ranked lower than a shared car or walking), Spearman's rho correlation is used. The Spearman's Correlation Coefficient (1), which is represented by $\rho$, is a nonparametric measure of the strength and direction of the association that exists between two ranked variables and provides a numerical value of the degree of correlation or non-correlation (1):

$$
\rho=1-\frac{6 \sum d_{i}^{2}}{n\left(n^{2}-1\right)}
$$

where $n$ is the number of data points of the two variables, and $d_{i}$ is the difference in the ranks of the ith element of each random variable considered. The Spearman correlation coefficient, $\rho$, can take values from +1 to -1 .

- $\quad \rho=+1$ indicates a perfect rank association;

- $\quad \rho 0$ indicates no association between ranks, and the closer $\rho$ is to zero, the weaker the association between the ranks;

- $\quad \rho=-1$ indicates a perfect negative rank association.

However, The Spearman correlation has several limitations because it determines the strength and direction of the monotonic relationship between two variables rather than the strength and direction of the linear relationship between two variables. This method was preferred to compare the results obtained from the Romanian sample and for the results from the other countries where the same survey was applied [45].

In the present paper, we only presented significant Spearman correlations and coefficients related to the correlation between socio-economic characteristics and A-related parameters.

The investigation determining how the respondents chose the mode of transportation used for their main travel purposes (Table 5) resulted in the conclusion that the respondents who use personal cars are not interested in the travel costs or the environmental impact of their travel but that they are concerned reliability, travel time to their destination, safety, and personal security. On the other hand, those using shared modes of transportation (public transport, shared cars, or shuttle service to work) or those using active modes of transportation (bicycle, walking) are more interested in travel costs and the environmental aspects and are satisfied with the availability of connections with other modes of transportation.

Table 5. Main mode of transportation used and its determinants (Source: Authors' survey data).

\begin{tabular}{|c|c|c|c|c|c|c|c|c|c|c|c|c|}
\hline & 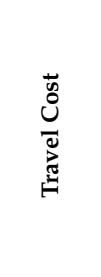 & 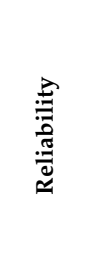 & 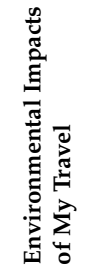 & 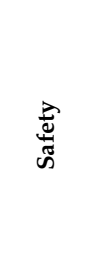 & 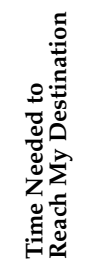 & 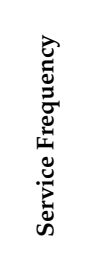 & 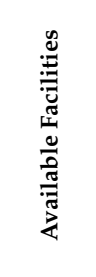 & 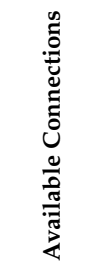 & 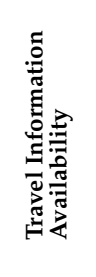 & 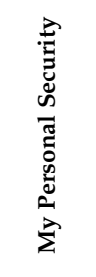 & 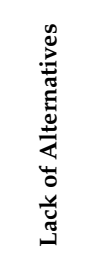 & 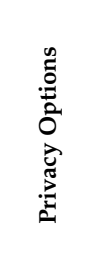 \\
\hline $\begin{array}{l}\text { Main mode of } \\
\text { transport used } \\
\text { for the most } \\
\text { important } \\
\text { journey }\end{array}$ & $0.422 * *$ & $\underset{*}{-0.143}$ & $0.591 * *$ & $-\underset{* *}{0.217}$ & $-\underset{* *}{0.174}$ & $-\underset{* *}{0.171}$ & $-\underset{* *}{0.301}$ & $0.208^{* *}$ & -0.043 & $-\underset{* *}{0.372}$ & -0.088 & $-\underset{* *}{0.218}$ \\
\hline
\end{tabular}

* Correlation is significant at the 0.05 level (2-tailed). ${ }^{* *}$ Correlation is significant at the 0.01 level (2-tailed). 
The potential to travel in an AV without the supervision of a human operator (Table 6) is influenced inter alia by gender, with women being more confident while travelling without the supervision of a human operator, while those in households without a car have more confidence in travelling in an AV with a human operator in the vehicle. In addition, the option to travel in an AV with an in-vehicle or remote operator was preferred by the younger respondents. Furthermore, those who use personal cars for travel purposes and those who have used adaptive cruise control (ACC) are more likely to travel in an AV if it has a human operator. From this, it can be concluded that people who use shared forms of transportation are not so concerned about the way an AV is driven.

Table 6. Spearman correlation between socio-economic characteristics of the sample and potential use of AVs (Source: Authors' survey data processing).

\begin{tabular}{|c|c|c|c|c|c|c|}
\hline Travel in an $\mathrm{AV}$ & Gender & Age & $\begin{array}{c}\text { Members in the } \\
\text { Household who } \\
\text { Need Caring } \\
\text { Responsibility }\end{array}$ & $\begin{array}{l}\text { Operational } \\
\text { Cars in the } \\
\text { Household }\end{array}$ & $\begin{array}{c}\text { Use of } \\
\text { Adaptive } \\
\text { Cruise Control }\end{array}$ & $\begin{array}{l}\text { Transport } \\
\text { Mode Used }\end{array}$ \\
\hline $\begin{array}{l}\text { WITH the supervision of a } \\
\text { human operator } \\
\text { IN THE VEHICLE }\end{array}$ & 0.024 & $-0.116^{*}$ & -0.072 & $-0.162^{* *}$ & $0.210 * *$ & $0.140 *$ \\
\hline $\begin{array}{c}\text { WITH the REMOTE } \\
\text { supervision of a human } \\
\text { operator at a distant location }\end{array}$ & 0.000 & $-0.166^{* *}$ & $-0.120^{*}$ & -0.089 & 0.085 & 0.093 \\
\hline $\begin{array}{l}\text { WITHOUT the supervision } \\
\text { of a human operator }\end{array}$ & $0.129 *$ & -0.088 & -0.109 & -0.035 & -0.089 & -0.011 \\
\hline
\end{tabular}

* Correlation is significant at the 0.05 level (2-tailed). ${ }^{* *}$ Correlation is significant at the 0.01 level (2-tailed).

Agreeing to allow one's own child to travel alone in an AV (Tables 7 and 8) is influenced by age, and older people who indicated using cars as their main form of transportation indicated that they would be more comfortable with their children travelling in an AV if there was human supervision (in the vehicle or remotely). This complements the motivations for personal car use (Table 2), safety and personal security. Moreover, the decision to share an AV with other people (themselves or their children under 16) (Table 5) was influenced by gender and age, with women being more accepting of travelling with strangers, and young people being more likely to accept the idea of their children travelling in a shared AV. The level of education and the number of family members also influenced this decision, with highly educated people being less confident in shared vehicles and respondents from smaller families being more willing to accept travelling or their children travelling with unknown people. In addition, the respondents who indicated that they did not have any disabilities indicated that they were more willing to accept travelling in an AV with other people.

Table 7. Spearman correlation between socio-economic characteristics of the sample and potential use of AVs by children under 16 (Source: Authors' survey data).

\begin{tabular}{ccccc}
\hline $\begin{array}{c}\text { I Would Allow My Children under } \\
\mathbf{1 6} \text { to Travel in an AV }\end{array}$ & Age & $\begin{array}{c}\text { Members in the } \\
\text { Household }\end{array}$ & $\begin{array}{c}\text { Operational Cars in } \\
\text { the Household }\end{array}$ & Transport Mode Used \\
\hline $\begin{array}{c}\text { WITH the supervision of a human } \\
\text { operator IN THE VEHICLE }\end{array}$ & $-0.114^{*}$ & -0.037 & $-0.119^{*}$ & $0.161^{* *}$ \\
\hline $\begin{array}{c}\text { WITH the REMOTE supervision of a } \\
\text { human at a distant location }\end{array}$ & $-0.184^{* *}$ & -0.005 & -0.001 & $0.131^{*}$ \\
\hline $\begin{array}{c}\text { WITHOUT the supervision of a } \\
\text { human operator }\end{array}$ & -0.079 & $-0.141^{*}$ & 0.012 & 0.053 \\
\hline
\end{tabular}

${ }^{*}$ Correlation is significant at the 0.05 level (2-tailed). ${ }^{* *}$ Correlation is significant at the 0.01 level (2-tailed). 
Table 8. Spearman correlation between socio-economic characteristics of the sample and potential use of AVs by the children under 16 (Source: Authors' survey data).

\begin{tabular}{|c|c|c|c|c|c|c|c|c|c|}
\hline $\begin{array}{l}\text { I Would Accept } \\
\text { to Travel with } \\
\text { Other Unknown } \\
\text { People in an AV }\end{array}$ & 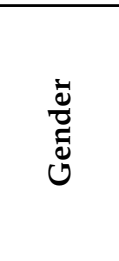 & $\stackrel{\circ 0}{4}$ & 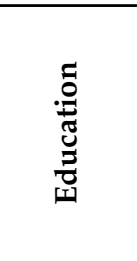 & 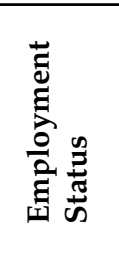 & 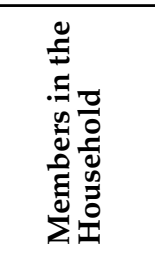 & 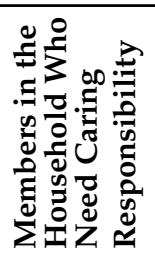 & 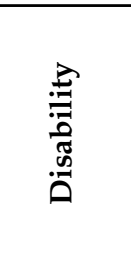 & 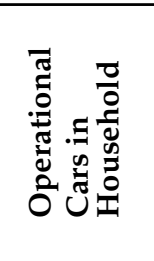 & 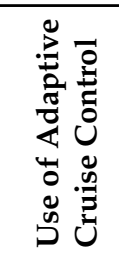 \\
\hline MYSELF & 0.140 * & $\underset{* *}{0.190}$ & $-0.121 *$ & 0.133 * & $-0.127 *$ & 0.055 & $0.159 * *$ & $-0.182 * *$ & $0.175^{* *}$ \\
\hline $\begin{array}{c}\text { For MY } \\
\text { CHILDREN }<16\end{array}$ & 0.076 & $-0.138^{*}$ & -0.062 & 0.043 & $-0.229 * *$ & $-0.160 * *$ & 0.083 & $-0.132 *$ & 0.081 \\
\hline
\end{tabular}

Table 9 presents the results of the Spearman correlation between the socio-economic characteristics of the sample and the willingness to buy an AV. Younger people, those with low income, those who have had car accidents, or those who use ACC are more confident in buying an AV under any condition (availability, affordability, safety, and reliability). Responders with a lower level of education, women, and younger respondents would only buy an AV after seeing them being used by others.

Table 9. Spearman correlation between socio-economic characteristics of the sample and willingness to buy an AV (Source: Authors' survey data).

\begin{tabular}{|c|c|c|c|c|c|c|c|c|}
\hline $\begin{array}{c}\text { Willingness To } \\
\text { Buy an AV }\end{array}$ & $\underset{0}{\stackrel{ \pm}{C}}$ & $\ddot{\&}$ & 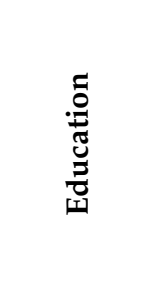 & 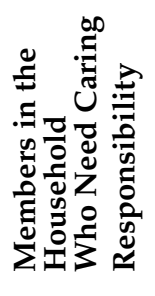 & 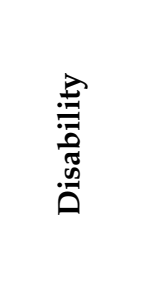 & 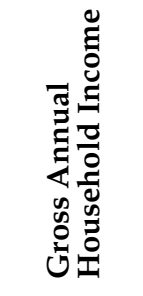 & 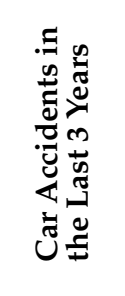 & 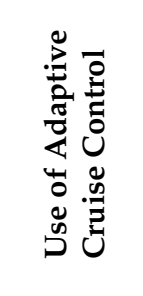 \\
\hline $\begin{array}{l}\text { As soon as they } \\
\text { become available }\end{array}$ & -0.003 & $-0.203^{* *}$ & -0.083 & -0.084 & -0.111 & -0.131 * & $0.132 *$ & $-0.170 * *$ \\
\hline $\begin{array}{l}\text { As soon as they } \\
\text { become affordable }\end{array}$ & 0.020 & $-0.191^{* *}$ & 0.000 & -0.070 & $-0.199 * *$ & $-0.147^{* *}$ & $0.147^{* *}$ & $-0.145 *$ \\
\hline $\begin{array}{l}\text { As soon as I am } \\
\text { convinced about } \\
\text { their usefulness }\end{array}$ & -0.075 & $-0.185^{* *}$ & -0.015 & -0.072 & $-0.182^{* *}$ & $-0.151^{* *}$ & $0.139 *$ & -0.123 * \\
\hline $\begin{array}{c}\text { As soon as I am } \\
\text { convinced about } \\
\text { their safety }\end{array}$ & -0.087 & $-0.181^{* *}$ & -0.027 & -0.096 & $-0.202 * *$ & $-0.126^{*}$ & 0.083 & -0.043 \\
\hline $\begin{array}{l}\text { As soon as I am } \\
\text { convinced about } \\
\text { their reliability }\end{array}$ & -0.027 & $-0.192^{* *}$ & -0.078 & $-0.172^{* *}$ & $-0.147^{* *}$ & -0.133 * & 0.053 & -0.044 \\
\hline $\begin{array}{l}\text { Only after I see } \\
\text { them being used } \\
\text { by others first }\end{array}$ & -0.127 * & $-0.147^{* *}$ & $-0.172^{* *}$ & -0.090 & 0.041 & -0.071 & -0.079 & 0.107 \\
\hline
\end{tabular}

*. Correlation is significant at the 0.05 level (2-tailed). ${ }^{* *}$. Correlation is significant at the 0.01 level (2-tailed).

The socio-economic characteristics of the respondents on how they perceive the benefits and concerns of AVs deployment show various levels of influence. The respondents were asked for their opinions on a set of eight types of presumed benefits (Table 10) and a set of seven presumed threats (Table 11) resulting from AV deployment. It was found that women believe that $\mathrm{AVs}$ will increase traffic congestion, while men are more confident that $\mathrm{AVs}$ will (i) reduce traffic congestion, (ii) allow the time that is usually spent travelling to 
be used for non-driving activities, (iii) reduce greenhouse gas emissions, and (iv) reduce the need for professional drivers. In addition, younger people are more confident in the benefits of AVs, such as reductions in travel stress and green gas emissions, improvements in mobility options and decreases in travel time. Furthermore, people with disabilities consider that AVs will increase the risks associated with personal assault or privacy. These concerns were also considered by the respondents with higher levels of income. The number of members per household also had an influence on the benefits or concerns related to $\mathrm{AVs}$. Responders from smaller households believe that $\mathrm{AVs}$ will improve mobility options, while those from larger households believe that $\mathrm{AVs}$ will increase privacy risks and reduce the freedom of travel. People who have experienced car accidents are more confident in $\mathrm{AV}$-related benefits, such as reducing the number of accidents, traffic congestion, or travel stress, and decreasing the travel time. The same opinion is shared by those who have used ACC in terms of the potential reduction in travel stress and making travelling more comfortable. Those who indicated that they drive more often indicated that AVs will reduce the pleasure of driving.

Table 10. Spearman correlation between socio-economic characteristics of the sample and potential benefits of AVs (Source: Authors' survey data).

\begin{tabular}{|c|c|c|c|c|c|c|c|c|}
\hline & 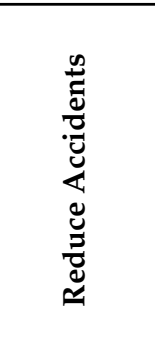 & 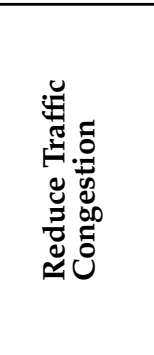 & 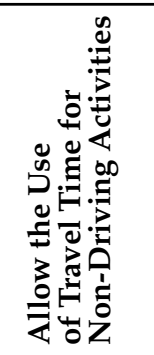 & 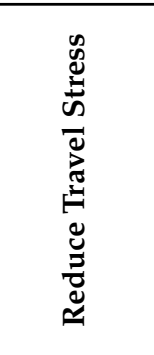 & 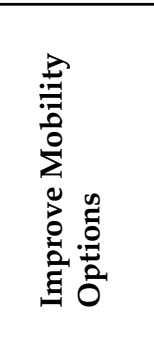 & 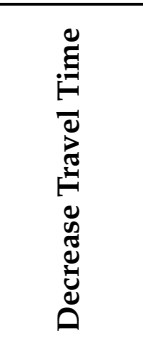 & 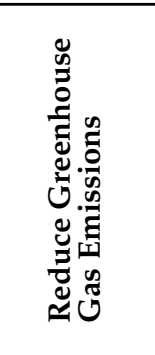 & 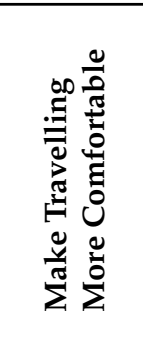 \\
\hline Gender & 0.083 & $0.168^{* *}$ & $0.153^{* *}$ & 0.049 & $0.155^{* *}$ & 0.045 & $0.120 *$ & 0.045 \\
\hline Age & $-0.240 * *$ & $-0.148^{* *}$ & $-0.175^{* *}$ & $-0.260 * *$ & $-0.221^{* *}$ & $-0.136^{*}$ & $-0.199 * *$ & $-0.198 * *$ \\
\hline Employment status & 0.05 & 0.065 & 0.105 & -0.004 & 0.112 & 0.102 & $0.114^{*}$ & -0.019 \\
\hline $\begin{array}{l}\text { Members in the } \\
\text { household }\end{array}$ & -0.09 & -0.067 & 0.004 & -0.045 & $-0.128 *$ & 0.03 & -0.029 & -0.064 \\
\hline $\begin{array}{l}\text { Members in the } \\
\text { household who need } \\
\text { caring responsibility }\end{array}$ & -0.120 * & -0.093 & -0.097 & -0.07 & -0.088 & -0.02 & -0.004 & -0.051 \\
\hline Disability & -0.11 & -0.075 & 0.006 & $-0.159^{* *}$ & -0.008 & -0.1 & 0.088 & $-0.124^{*}$ \\
\hline $\begin{array}{c}\text { Gross annual } \\
\text { household income }\end{array}$ & $-0.114 *$ & -0.022 & -0.043 & -0.131 * & -0.069 & -0.093 & -0.009 & -0.114 * \\
\hline Driving license & -0.054 & -0.047 & -0.04 & $-0.157^{* *}$ & -0.018 & -0.042 & -0.04 & -0.109 \\
\hline $\begin{array}{l}\text { Operational cars in } \\
\text { the household }\end{array}$ & -0.04 & 0.063 & -0.09 & 0.012 & -0.07 & $0.144^{*}$ & 0.03 & 0.068 \\
\hline
\end{tabular}

${ }^{*}$ Correlation is significant at the 0.05 level (2-tailed). ${ }^{* *}$ Correlation is significant at the 0.01 level (2-tailed). 
Table 11. Spearman correlation between socio-economic characteristics of the sample and potential concerns about AVs (Source: Authors' survey data).

\begin{tabular}{|c|c|c|c|c|c|c|c|}
\hline & 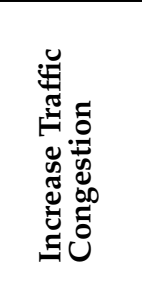 & 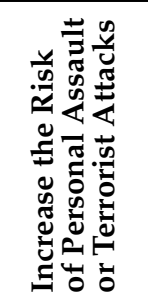 & 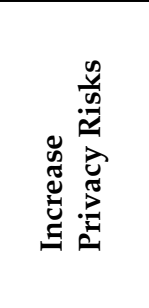 & 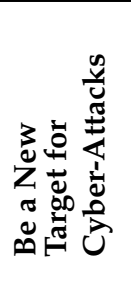 & 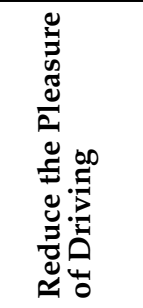 & 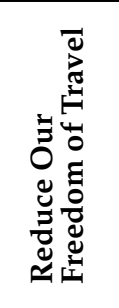 & 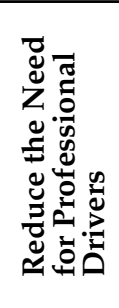 \\
\hline Gender & $-0.121 *$ & 0.074 & 0.095 & $0.159^{* *}$ & $0.179 * *$ & 0.033 & $0.182 * *$ \\
\hline Age & 0.064 & 0.078 & 0.028 & -0.01 & 0.099 & 0.039 & -0.043 \\
\hline Employment status & -0.062 & 0.097 & 0.07 & $0.146^{*}$ & -0.058 & 0.006 & 0.029 \\
\hline Members in the household & 0.06 & 0.104 & $0.115^{*}$ & 0.074 & 0.035 & $0.123 *$ & 0.032 \\
\hline $\begin{array}{l}\text { Members in the household } \\
\text { who need caring } \\
\text { responsibility }\end{array}$ & -0.006 & 0.049 & 0.094 & -0.038 & 0.008 & $0.119 *$ & -0.023 \\
\hline Disability & 0.039 & $0.142 *$ & $0.129 *$ & 0.021 & $0.126^{*}$ & 0.102 & 0.038 \\
\hline $\begin{array}{l}\text { Gross annual household } \\
\text { income }\end{array}$ & -0.03 & $0.129 *$ & $0.149^{* *}$ & 0.061 & 0.069 & 0.069 & -0.029 \\
\hline Driving license & -0.005 & $0.126^{*}$ & 0.031 & 0.102 & -0.088 & -0.034 & 0.031 \\
\hline $\begin{array}{l}\text { Operational cars in the } \\
\text { household }\end{array}$ & -0.054 & -0.084 & 0.01 & -0.061 & 0.051 & 0.111 & 0.006 \\
\hline $\begin{array}{c}\text { Car accidents in the last } 3 \\
\text { years }\end{array}$ & -0.081 & $-0.151^{* *}$ & $-0.160^{* *}$ & -0.043 & -0.018 & 0.014 & -0.049 \\
\hline $\begin{array}{l}\text { Use of Adaptive Cruise } \\
\text { Control }\end{array}$ & -0.001 & $0.147^{* *}$ & 0.108 & $0.140 *$ & $-0.120 *$ & -0.06 & -0.03 \\
\hline Transport mode used & -0.007 & 0.025 & -0.048 & 0.022 & $-0.198^{* *}$ & -0.113 & 0.078 \\
\hline
\end{tabular}

${ }^{*}$ Correlation is significant at the 0.05 level (2-tailed). ${ }^{* *}$ Correlation is significant at the 0.01 level (2-tailed).

\section{Discussion, Conclusions, and Recommendations}

\subsection{Assumption Assessment and Discussion}

Assumption 1: There is a poor focus on ACT planning in strategic documents in Romania.

In the current Romanian mobility and transport planning documents, there is not an explicit focus on developing ACT infrastructure, though few pilot projects exploring AVs use are planned. However, other projects supporting the digitization of transport have been deployed, such as 5G infrastructure, smart traffic management, and smart parking. We consider these new, smart infrastructures to be supportive of the future development of an ACT ecosystem.

Assumption 2: The current spatial patterns of large cities and of Functional Urban Areas (FUAs) create premises for unsustainable mobility patterns based on ACT use.

The extensive and partially sprawling and low-density urban developments that are largely residential and poorly equipped with facilities and that have urbanized large peripheric and suburban areas are functionally dependent on large core cities. Moreover, spatial expansion has not been sufficiently followed and served by the development of public transport to achieve acceptable and inclusive accessibility to collective transport. These patterns of metropolitan spatial growth have generated high levels of unsustainable commuting based on car use, with a wide range of the above-mentioned externalities. It can be assumed that these spatial and functional patterns, if not corrected, can further create negative premises for unsustainable mobility behaviour based on the private use of ACTVs. Even though the core cities of the FUAs, usually have a satisfactory public transport supply, the current mobility behaviour is unsustainably focused on car use in 
the absence of dissuasive measures that have been designed through mobility policies. As shown by the survey analysed in this paper, this preference is also related to AV use.

Even if ACT systems will be electric and will have a low environmental impact, continuing car-centric mobility behavioural patterns will continue to increase the high level of unsustainable space consumption since AVs enable more people to travel in cars alone.

A positive potential to be explored is how ACT systems could improve the transportation supply (collective transport, shared-transport, on-demand transport) in the periphery and in peri-urban areas, making them an attractive alternative to car use.

Assumption 3: Romanian citizens have limited AV knowledge.

There were some differences in the survey responses regarding AV-related knowledge, depending on the age of the participant: older participants who were older than 60 years of age demonstrated lower knowledge of AVs, confirming the assumption; nevertheless, younger people (20-39) have better knowledge, presumably due to their digital abilities, confirming the literature review results in [41,42,44,45].

Assumption 4: The perceptions of Romanian citizens are widely similar to those of citizens of other countries around the world.

Similar to the results obtained by $[14,44]$, who discussed the results of the same COST WISE ACT survey, we found that the attitudes/perceptions of Romanian citizens fall within the same trends in terms of security, vehicle sharing with other occupants, and the reluctance of women to use AVs [14]. Similar to [37,38], men have more positive attitudes towards AVs.

However, the survey respondents expressed some significant concerns, such as in terrorist attacks, cyber security, and privacy risks, which may hinder AV uptake and use in Romania and is consistent with previous research at the international level [38] and in other EU countries [52].

When it comes to the general attitudes towards AVs in the SEE countries, we can say that the hypothesis is only partially confirmed: while the perceptions in Romanian citizens are similar to those found in Poland [46], largely expressing a positive view on AVs, most people in Serbia are sceptical about self-driving cars [47].

When travelling, either by themselves or with children under the age of 16, most of the respondents in Romania indicated preferring a human operator to be present in the car. The research shows how important safety is for users to adopt AVs and that a considerable proportion of the respondents do not fully trust the SAE Level 5 AVs for their journeys in the absence of human control, confirming the results of the literature review and the survey results in the WISE ACT countries [14,45]. Besides safety, another important criterion that will convince people to buy an automated vehicle is its reliability, confirming the results in [38].

Assumption 5: Orientation towards unsustainable forms of travel with AVs (individual use of AVs) will be maintained and accentuated, and there is poor willingness to use SAVs.

Contrary to the findings in the literature from other countries [53] and to the expected sustainability benefits [50], the survey highlights that current mobility trends continue in relation to the future use of AVs, underlining the preferences of citizens in Romania for individual car use and their reduced willingness to travel in automated shared vehicles.

Nevertheless, the decision to share an AV with other people, (themselves or their children under 16) is influenced by gender and age, in that women are more likely to accept travelling with unknown people, and young people are more likely than older people to allow their children to travel with unknown people in a shared AV, similar to the findings in [54], which suggested that women who were 26-30 years old are more likely to used shared services.

\subsection{Conclusions and Recommendations towards ACT Deployment in Romanian Cities}

The research may conclude that the way transport officials and planners design the mobility developments using AVs is the key to determining whether this technology will be accepted or rejected in Romania, what (social, environmental, spatial, economic) impact their deployment will have, and at what level broader sustainability goals will be met. 
Factors determining attitudes towards AVs should be investigated further to help allocate resources towards the sustainable shaping of future ACT models.

The literature indicates that AVs are expected to be safer, cleaner (electric), and more efficient in their use of the road space, will allow productive travel time, and be available to all population groups [26]. However, some of these assumed benefits could be partially replaced by negative impacts if car-centric mobility behaviour is not discouraged by sustainable mobility policies if car-dependency in suburban and peri-urban areas or not corrected or if the current urban sprawl expands geographically. In this context, the implementation of automated vehicles could lead to an increase in the share and volume of car use (for those who do not currently drive, children, the elderly, the disabled, those who will own and/or use private automated vehicles), both in large cities and in their peri-urban areas. Given the reluctance to use shared vehicles [14], public transport could lose more of its attractiveness and modal share [33]. Commuting by car could increase in volume and length due to people's greater acceptance of travelling longer distances if they can have a double use for the travel time so that they can complete other activities $[26,28,33]$.

This paper represents an initial exploratory study in Romania, connecting the analysis of the spatial development characteristics influencing mobility patterns, strategic framework that is relevant for future ACT deployment, and citizen perceptions and attitudes towards automated vehicles (AVs), influencing future mobility behaviour related to ACT.

Following the results of the study, we have identified several main recommendations for the sustainable development of future ACT systems in Romania, which aim to harness their foreseeable positive potential while mitigating their negative impact.

As per the surveys, the respondents in Romania appeared to be generally positive about the potential benefits that may be derived from AV deployment, similar to the results of other studies in the SEE region [46,47].

However, because of concerns arising from the limited knowledge about AVs, there is a need to increase the awareness and acceptance of both citizens other stakeholders through information, communication campaigns, and pilot demonstrations aimed at i. a better understanding of the new features and benefits of $\mathrm{ACT}$, ii. mitigating the negative perceptions about safety (travelling in the AV and on-street interaction with AV), security, costs, and the shared use of AVs, and iii. raising willingness to use AVs, especially as shared and collective transport, for AV implementation to be successful. Current and future AV-based shared mobility should be explained to change the citizen mobility habits and to develop a new smart and sustainable mobility culture. Awareness should also be raised regarding the environmental impact of the different modes of transportation.

Upgraded and more mature mobility policies should be developed to mitigate current unsustainable mobility habits and to prevent their accentuation through AV use, such as individual car-centric travel behaviour, long commuting distances, and high preferences for car ownership over shared mobility. New mobility planning methods and models for $\mathrm{AV}$ integration into urban mobility systems should be incorporated into the next generation of SUMPs, [33] especially for the ambitious smart cities of the future.

Finally, it is necessary to improve the urban planning strategic framework to create spatial premises for sustainable mobility and to develop consistent research on the relationship between the (re)modelling of urban environments and ACT systems. The sprawling, car-oriented spatial development that could generate high AV volumes and commuting distances, in what Cavoli names "technology-led" instead of "technology-fed" smart territories [26] has to be banned. The compact development, functional mixity, polycentric development, transit-oriented development models and a proper density for supporting public transportation need to be better regulated for sustainable spatial development $[1,3,6]$. Prospective studies on the future spatial demands of ACT systems should identify models for how to re-design and regulate these systems so that cities can adapt to them sustainably. This is to avoid adopting dysfunctional patterns such as the "adaptation of cities to the cars" seen in the 1950s and 1960s. It is necessary for mobility planning and spatial planning to be better integrated in order for AV deployment to be achieved. 
There are, however, some limitations in the study, especially those related to the online survey: first, the sample in Romania was not diverse enough to capture the perceptions that all of the respondents had to all of the categories, as most of the respondents were highly educated, active people, most of whom were aged 30-49. Since the participants were digitally educated, the survey excluded the citizens who did not have access to or who are not familiar with the internet [45]; secondly, because awareness of AVs is limited and there was no individual AV testing stage before the survey, the responses are based on personal assumptions. It should also be noted that the respondents in most of the other studies in the SEE countries were not a representative sample, and often, the number of responses was relatively low (Table 2), which may reduce their comparability.

Further research should examine the design of sustainable and contextualised ACT schemes that address specific transport improvement needs in both large cities and their FUAs in SEE countries. ACT services have to be designed in different areas (inner-city, suburb, peri-urban area) for multimodal accessibility that is based on low-carbon and low space-consuming modes and for a better liveability in terms of (i) metropolitan, local, and-zonal transport services (AV-based public transport) and shared mobility and (ii) Automated Connected Transport mobility schemes (car-sharing, ride-sharing, ride-hailing) as well as on-demand transport provisions in areas that currently have poor accessibility to public transport. ACT systems should be designed to make mobility more efficient, safe, comfortable, and personalised while also supporting sustainable and less car-centric mobility habits. The future demands for mobility must be studied and understood in the context of other general trends or risks such as ageing, the digital marginalisation of elders, gender inequity in mobility, etc. Moreover, future research should consider the integration of the new ACT systems with the traditional mobility ecosystems, planning and practices, through multimodal and intermodal thinking and through Mobility as a Service (MaaS) approaches. New mobility planning methods and models for AVs integration in the urban mobility systems should be incorporated into the next generation of SUMPs, and to consider as well at a wider dimension (respectively at regional transportation plans [55] when it will be required by the Romanian legislation), knowing that the influence of urban transport goes beyond the urban area borders. The new ecosystem of new AV-based public transport models and new shared, automated mobility should be designed through a quadruple helix approach, involving the four main categories of actors in the innovation system: science (research and academia), policy, industry, and society.

Our research was not focused on the technological solutions nor on the economic aspects of AVs in Romania, yet for an integrative approach and future ACT deployment, further work will need to address thoroughly these dimensions.

Finally, we expect our findings to be relevant to all stakeholders involved in the development of future smart mobility, allowing them to contribute to the debate on automated and connected transport, especially in SEE countries.

Author Contributions: Conceptualization, L.A., M.H.N. and O.L.; data curation, L.A. and O.L.; formal analysis, L.A. and M.H.N.; funding acquisition, O.L.; investigation, L.A. and M.H.N.; methodology, L.A., M.H.N. and O.L.; project administration, O.L.; resources, L.A. and O.L.; software, L.A.; supervision, M.H.N.; validation, L.A., M.H.N. and O.L.; visualization, L.A.; writing-original draft, L.A., M.H.N. and O.L.; writing-review and editing, L.A., M.H.N. and O.L. All authors have read and agreed to the published version of the manuscript.

Funding: This study forms part of an international survey focusing on AVs conducted by WISEACT (COST Action CA16222Wider Impacts and Scenario Evaluation of Autonomous and Connected Transport).

Institutional Review Board Statement: This survey followed the Self-Assessment and Governance in Ethics guidelines of the University of Surrey, UK. Only anonymous data have been collected through this survey, so no personal data regulation (e.g., GDPR) is applicable, as assessed by the University of Udine. 
Informed Consent Statement: Informed consent was obtained from all subjects who completed the survey in Romania.

Data Availability Statement: Survey data are available upon request according to the WISE-ACT IPR. They will be made available as OpenData after the completion of WISE-ACT via https:/ / www. wise-act.eu.

Acknowledgments: The authors acknowledge the support provided by the WISE-ACT COST Action CA16222, which supported the survey.

Conflicts of Interest: The authors declare no conflict of interest.

\section{References}

1. Banister, D. The Sustainable Mobility Paradigm. Transp. Policy 2008, 15, 73-80. [CrossRef]

2. Banister, D.; Pucher, J.; Lee-Gosselin, M. Making Sustainable Transport Politically and Publicly Acceptable: Lessons from the EU, USA and Canada; Edward Elgar Publishing: Cheltenham, UK, 2007; pp. 17-50.

3. Negulescu, M.H. Mobilitate Și Formă Urbană—Aspecte Teoretice; Editura Universitară „Ion Mincu”: Bucharest, Romania, 2011; ISBN 978-606-638-004-1.

4. $\quad$ Duany, A.; Plater-Zyberk, E.; Speck, J. Suburban Nation: The Rise of Sprawl and the Decline of the American Dream; North Point Press: Albany, CA, USA, 2000.

5. Banister, D.; Hickman, R. How to Design a More Sustainable and Fairer Built Environment: Transport and Communications. IEE Proc. Intell. Transp. Syst. 2006, 153, 276-291. [CrossRef]

6. Banister, D. The Sustainable Mobility Paradigm +10. In Transport Policy; Transport Studies Unit, School of Geography and the Environment, Oxford University: Oxford, UK, 2018; Volume 15, pp. 73-80.

7. Jacobs, J. The Death and Life of Great American Cities; Reissue Edition; Vintage: New York, NY, USA, 1992; ISBN 978-0-679-74195-4.

8. Gehl, J.; Rogers, L.R. Cities for People; Illustrated Edition.; Island Press: Washington, DC, USA, 2010; ISBN 978-1-59726-573-7.

9. Duany, A.; Speck, J.; Lydon, M. The Smart Growth Manual, 1st ed.; McGraw Hill: New York, NY, USA, 2009; ISBN 978-0-07-137675-4.

10. European Commission. Communication from the Commission to The European Parliament, The Council, The European Economic and Social Committee and The Committee of The Regions: Sustainable and Smart Mobility Strategy—Putting European Transport on Track for the Future \{SWD(2020) 331 Final\}. Available online: https:/ / eur-lex.europa.eu/legal-content/EN/TXT/HTML/ ?uri=CELEX:52020DC0789\&from=EN (accessed on 14 February 2022).

11. Negulescu, M.H. RevistaInfrastructura de Transport şi Mobilitate în Bucureşti/Infrastructure of Transports and Mobility/Infrastructure de Transport et Mobilité; URBANISMUL: Bucharest, Romania, 2014; p. 169.

12. Negulescu, M.H. Practica Urbanistică de Remodelare Sustenabilă a Mobilităţii; Editura Universitară" Ion Mincu": Bucharest, Romania, 2011.

13. Negulescu, M.H. Considerations on the Management of Accessibility Improvement Impact on Land Use. JULP 2018, 3, 37-50. [CrossRef]

14. Polydoropoulou, A.; Tsouros, I.; Thomopoulos, N.; Pronello, C.; Elvarsson, A.; Sigpórsson, H.; Dadashzadeh, N.; Stojmenova, K.; Sodnik, J.; Neophytou, S.; et al. Who Is Willing to Share Their AV? Insights about Gender Differences among Seven Countries. Sustainability 2021, 13, 4769. [CrossRef]

15. Create-Home. Available online: http:/ / www.create-mobility.eu/ (accessed on 21 January 2022).

16. LEGE 350 06/07/2001-Portal Legislativ. Available online: http:/ / legislatie.just.ro/Public/DetaliiDocument/29453 (accessed on 29 November 2021).

17. Ministerul Transporturilor Master Planul General de Transport. Available online: http:/ /www.mt.gov.ro/web14/strategia-intransporturi/master-plan-general-transport (accessed on 15 February 2022).

18. Ministerul Transporturilor. Strategia Pentru Transport Durabil pe Perioada 2007-2013 şi 2020, 2030. Available online: http:/ /www. mt.gov.ro/web14/documente/strategie/strategii_sectoriale/strategie_dezvoltare_durabila_noua_ultima_forma.pdf (accessed on 27 January 2022).

19. Ministerul Transporturilor si Infrastructurii Strategia de Transport Intermodal in Romania. Available online: http://mt.gov.ro/ web14/documente/strategie/strategii_sectoriale/strategie_de_transport_intermodal_text.pdf (accessed on 27 January 2022).

20. Ministerul Transporturilor, Infrastructurii si COmunicatiilor Strategia de Dezvoltare a Infrastructurii Feroviare. Available online: http:/ / www.cfr.ro/index.php/ct-menu-item-3/ct-menu-item-55/strategia-de-dezvoltare-a-infrastructurii-feroviare (accessed on 27 January 2022).

21. Iași Smart City. Available online: https:/ / iasismartcity.ro/ (accessed on 27 January 2022).

22. Strategia Smart City a Municipiului Pitești-Primăria Municipiului Pitești. Available online: https://www.primariapitesti.ro/ strategia-smart-city-a-municipiului-piteti-p177 (accessed on 27 January 2022).

23. Strategie Smart City 2021-2027. Available online: https:/ / primariacalarasi.ro/index.php/directiile-primariei/directia-programesi-dezvoltare-locala/strategie-smart-city (accessed on 15 February 2022).

24. Stanilov, K. The restructuring of non-residential uses in the post-socialist metropolis. In The Post-Socialist City: Urban Form and Space Transformations in Central and Eastern Europe after Socialism; Stanilov, K., Ed.; The GeoJournal Library; Springer: Dordrecht, The Netherlands, 2007; pp. 73-99, ISBN 978-1-4020-6053-3. 
25. Bouzarovski, S.; Stanilov, K.; Sýkora, L. (Eds.) Confronting Suburbanization: Urban Decentralization in Postsocialist Central and Eastern Europe. Chichester: Wiley Blackwell. Int. J. Urban Reg. Res. 2016, 40, 249-251. [CrossRef]

26. Cavoli, C.; Phillips, B.; Cohen, T.; Jones, P. Social and Behavioural Questions Associated with Automated Vehicles: A Literature Review; UCL Transport Institute: London, UK, 2017.

27. Taubenböck, H.; Gerten, C.; Rusche, K.; Siedentop, S.; Wurm, M. Patterns of Eastern European Urbanisation in the Mirror of Western Trends-Convergent, Unique or Hybrid? Environ. Plan. B: Urban Anal. City Sci. 2019, 46, 1206-1225. [CrossRef]

28. Nikitas, A.; Thomopoulos, N.; Milakis, D. The Environmental and Resource Dimensions of Automated Transport: A Nexus for Enabling Vehicle Automation to Support Sustainable Urban Mobility. Annu. Rev. Environ. Resour. 2021, 46, 167-192. [CrossRef]

29. Emberger, G.; Pfaffenbichler, P. A Quantitative Analysis of Potential Impacts of Automated Vehicles in Austria Using a Dynamic Integrated Land Use and Transport Interaction Model. Transp. Policy 2020, 98, 57-67. [CrossRef]

30. Conlon, J.; Lin, J. Greenhouse Gas Emission Impact of Autonomous Vehicle Introduction in an Urban Network. Transp. Res. Rec. 2019, 2673, 142-152. [CrossRef]

31. Luca, O.; Sercaianu, M. Mobility Management in European Projects. Lessons Learned for Romania. Theor. Empir. Res. Urban Manag. 2011, 6, 54-66.

32. Pojani, E.; van Acker, V.; Pojani, D. Cars as a Status Symbol: Youth Attitudes toward Sustainable Transport in a Post-Socialist City Transp. Res. Part F Traffic Psychol. Behav. 2018, 58, 210-227. [CrossRef]

33. The Future of Mobility 3.0. Arthur D. Little. Available online: http://www.adlittle.com/en/insights/viewpoints/futuremobility-30 (accessed on 21 January 2022).

34. González-González, E.; Nogués, S.; Stead, D. Automated Vehicles and the City of Tomorrow: A Backcasting Approach. Cities 2019, 94, 153-160. [CrossRef]

35. Nikitas, A.; Michalakopoulou, K.; Njoya, E.T.; Karampatzakis, D. Artificial Intelligence, Transport and the Smart City: Definitions and Dimensions of a New Mobility Era. Sustainability 2020, 12, 2789. [CrossRef]

36. Stoma, M.; Dudziak, A.; Caban, J.; Droździel, P. The Future of Autonomous Vehicles in the Opinion of Automotive Market Users Energies 2021, 14, 4777. [CrossRef]

37. Schoettle, B.; Sivak, M. Public Opinion about Self-Driving Vehicles in China, India, Japan, the U.S., the U.K., and Australia; University of Michigan: Ann Arbor, MI, USA, 2014.

38. Kyriakidis, M.; Happee, R.; de Winter, J.C.F. Public Opinion on Automated Driving: Results of an International Questionnaire among 5000 Respondents. Transp. Res. Part F: Traffic Psychol. Behav. 2015, 32, 127-140. [CrossRef]

39. Rezaei, A.; Caulfield, B. Examining Public Acceptance of Autonomous Mobility. Travel Behav. Soc. 2020, 21, 235-246. [CrossRef]

40. Ahmed, S.S.; Pantangi, S.S.; Eker, U.; Fountas, G.; Still, S.E.; Anastasopoulos, P.C. Analysis of Safety Benefits and Security Concerns from the Use of Autonomous Vehicles: A Grouped Random Parameters Bivariate Probit Approach with Heterogeneity in Means. Anal. Methods Accid. Res. 2020, 28, 100134. [CrossRef]

41. Butler, L.; Yigitcanlar, T.; Paz, A. Factors Influencing Public Awareness of Autonomous Vehicles: Empirical Evidence from Brisbane. Transp. Res. Part F: Traffic Psychol. Behav. 2021, 82, 256-267. [CrossRef]

42. Kolarova, V.; Cherchi, E. Impact of Trust and Travel Experiences on the Value of Travel Time Savings for Autonomous Driving. Transp. Res. Part C: Emerg. Technol. 2021, 131, 103354. [CrossRef]

43. Chng, S.; Anowar, S.; Cheah, L. To Embrace or Not to Embrace? Understanding Public's Dilemma about Autonomous Mobility Services: A Case Study of Singapore. Case Stud. Transp. Policy 2021, 9, 1542-1552. [CrossRef]

44. Etzioni, S.; Hamadneh, J.; Elvarsson, A.B.; Esztergár-Kiss, D.; Djukanovic, M.; Neophytou, S.N.; Sodnik, J.; Polydoropoulou, A.; Tsouros, I.; Pronello, C.; et al. Modeling Cross-National Differences in Automated Vehicle Acceptance. Sustainability 2020, 12, 9765. [CrossRef]

45. Kyriakidis, M.; Sodnik, J.; Stojmenova, K.; Elvarsson, A.B.; Pronello, C.; Thomopoulos, N. The Role of Human Operators in Safety Perception of AV Deployment-Insights from a Large European Survey. Sustainability 2020, 12, 9166. [CrossRef]

46. Dudziak, A.; Stoma, M.; Kuranc, A.; Caban, J. Assessment of Social Acceptance for Autonomous Vehicles in Southeastern Poland. Energies 2021, 14, 5778. [CrossRef]

47. Cveticanin, L.; Ninkov, I. Pro and contra for self-driving car: Public opinion in Serbia. In Proceedings of the ICONST EST'21: International Conferences On Science And Technology, Budva, Montenegro, 8-10 September 2021; p. 378.

48. Hamadneh, J.; Esztergár-Kiss, D. The Influence of Introducing Autonomous Vehicles on Conventional Transport Modes and Travel Time. Energies 2021, 14, 4163. [CrossRef]

49. Bonnefon, J.-F.; Černy, D.; Danaher, J.; Devillier, N.; Johansson, V.; Kovacikova, T.; Martens, M.; Mladenovic, M.; Palade, P.; Reed, N.; et al. Ethics of Connected and Automated Vehicles: Recommendations on Road Safety, Privacy, Fairness, Explainability and Responsibility; Spatial Planning and Transportation Engineering Department of Built Environment: Espoo, Finland, 2020; ISBN 978-92-76-17868-2.

50. Taiebat, M.; Brown, A.L.; Safford, H.R.; Qu, S.; Xu, M. A Review on Energy, Environmental, and Sustainability Implications of Connected and Automated Vehicles. Environ. Sci. Technol. 2018, 52, acs.est.8b00127. [CrossRef]

51. Meyer-Waarden, L.; Cloarec, J. "Baby, You Can Drive My Car": Psychological Antecedents That Drive Consumers' Adoption of AI-Powered Autonomous Vehicles. Technovation 2021, 109, 102348. [CrossRef]

52. Maddox, J. Intelligent vehicles + infrastructure to address transportation problems-A strategic approach. In Proceedings of the 24th International Technical Conference on the Enhanced Safety of Vehicles (ESV), Gothemburg, Sweden, 8-11 June 2015 ; p. 12. 
53. Berrada, J.; Mouhoubi, I.; Christoforou, Z. Factors of Successful Implementation and Diffusion of Services Based on Autonomous Vehicles: Users' Acceptance and Operators' Profitability. Res. Transp. Econ. 2020, 83, 100902. [CrossRef]

54. Da Silva, D.C.; Astroza, S.; Batur, I.; Khoeini, S.; Magassy, T.B.; Pendyala, R.M.; Bhat, C.R. Are Millennials Really All That Different Than Generation X? An Analysis of Factors Contributing to Differences in Vehicle Miles of Travel; Department of Civil, Architectural and Environmental Engineering: Austin, TX, USA, 2019.

55. Russo, F.; Rindone, C. Regional Transport Plans: From Direction Role Denied to Common Rules Identified. Sustainability 2021, 13, 9052. [CrossRef] 